\title{
Precursor Structure of Chemically Modified Aluminum-tri-sec-Butoxide in Diethylene Glycol and Ethylene Glycol Monoethyl Ether
}

\author{
Kiyoharu TADANAGA and Tsutomu MINAMI \\ Department of Applied Materials Science, Graduate School of Engineering, Osaka Prefecture University, 1-1, Gakuen-cho, Sakai-shi 599-8531 \\ ジエチレングリコール及びエチレングリコールモノエチルエーテル中における \\ 化学修飾されたアルミニウムトリセカンダリーブトキシドの前駆体構造 \\ 忠永清治・南＼cjkstart努 \\ 大阪府立大学大学院工学研究科機能物質科学分野, 599-8531 堺市学園町 1-1
}

\begin{abstract}
Precursor structure of chemically modified $\mathrm{Al}(\mathrm{O}-\mathrm{sec}-\mathrm{Bu})_{3}$ with ethyl acetoacetate or diethanolamine, dissolved in diethylene glycol (DEG), ethylene glycol monoethyl ether (EGE), and sec-butyl alcohol (sec$\mathrm{BuOH}$ ), was investigated using ${ }^{27} \mathrm{Al} \mathrm{NMR} .{ }^{27} \mathrm{Al}$ NMR spectra revealed that the reaction of DEG or EGE with $\mathrm{Al}(\mathrm{O}-\mathrm{sec}-\mathrm{Bu})_{3}$ led to the formation of six-coordinated structural units. The precursor structure of $\mathrm{Al}(\mathrm{O}-\mathrm{sec}-$ $\mathrm{Bu})_{3}$ modified with ethyl acetoacetate in $\mathrm{EGE}$, which consisted of six- and five-coordinated structural units, was almost the same as that in DEG, but different from that in $s e c-\mathrm{BuOH}$, where four-coordinated structural units were also observed. In $\mathrm{Al}(\mathrm{O}-\mathrm{sec} \text {-Bu })_{3}$ modified with diethanolamine, five- and six-coordinated structural units were present in all the solvents used in this study and the effect of solvents on the coordination state was very small.

[Received November 17, 1999; Accepted January 18, 2000]
\end{abstract}

Key-words : Structure of precursor, Chemical modification, ${ }^{27} \mathrm{Al} N \mathrm{NR}$, Solvent

\section{Introduction}

Chemical modification of metal alkoxides with chelating agents like $\beta$-diketones and alkanolamines is known to be effective for the control of reactivities and condensation process of active metal alkoxides, such as $\mathrm{Al}-, \mathrm{Zr}-$ and Ti-alkoxides. ${ }^{1-5)}$ These alkoxide precursors can be used for the synthesis of organic-inorganic hybrid gels, ${ }^{2}$ ) the fine patterning of oxide thin films by photolysis, ${ }^{4), 5)}$ or multicomponent oxides. ${ }^{6}$ ) The structure of modified metal alkoxides affects the character and structure of bulk gels or gel films formed by the sol-gel process, and thus many studies have been carried out on the precursor structure. For example, the structure of chemically modified Alalkoxides has been studied using IR and ${ }^{27} \mathrm{Al} \mathrm{NMR}$ spectroscopies. ${ }^{1), 3), 7)-10)}$ We have already reported the precursor structure of aluminum-tri-sec-butoxide ( $\mathrm{Al}(\mathrm{O}$ sec- $\left.\mathrm{Bu})_{3}\right)$ dissolved in diacetone alcohol, 11$) \mathrm{Al}(\mathrm{O}-\mathrm{sec}-\mathrm{Bu})_{3}$ modified with different amounts of ethyl acetoacetate $(\mathrm{EAcAc}),{ }^{12)}$ and $\mathrm{Al}(\mathrm{O}-\mathrm{sec}-\mathrm{Bu})_{3}$ modified with alkanolamines. ${ }^{13)}$

Diethylene glycol $\left(\mathrm{HOC}_{2} \mathrm{H}_{4} \mathrm{OC}_{2} \mathrm{H}_{4} \mathrm{OH}, \mathrm{DEG}\right)$ has two hydroxyl groups and oxygen atom in the ether group, and has complexing ability. The structure of DEG is similar to diethanolamine $\left(\mathrm{HOC}_{2} \mathrm{H}_{4} \mathrm{NHC}_{2} \mathrm{H}_{4} \mathrm{OH}, \mathrm{DEA}\right)$, which is one of alkanolamines and is commonly used for chemical modification of metal alkoxides. ${ }^{\left.1{ }^{1}, 13\right)}$ It is thus expected that DEG has some contribution to the chemical modification when it is used as a solvent. In fact, DEG has been used to control hydrolysis and gelation process of active metal alkoxides. ${ }^{14)}$ When alkoxides or chemically modified ones are dissolved in DEG, the coordination states of the alkoxides may change through the coordination of DEG. In the case of aluminum alkoxides, the coordination state around $\mathrm{Al}$ atoms is easily observed by ${ }^{27} \mathrm{Al} \mathrm{NMR} \cdot{ }^{10)-13)}$ It is thus valuable to investigate the coordination state of $\mathrm{Al}$ alkoxides and chemically modified ones dissolved in DEG to understand the contribution of DEG to the chemical modification. In addition to DEG, ethylene glycol monoethyl ether $\left(\mathrm{C}_{2} \mathrm{H}_{5} \mathrm{OC}_{2} \mathrm{H}_{4} \mathrm{OH}, \mathrm{EGE}\right)$ was also used as a solvent in this study, since EGE has similar structure to DEG, in which it has only one hydroxy group.

In this study, the coordination states of chemically modified $\mathrm{Al}(\mathrm{O}-\mathrm{sec}-\mathrm{Bu})_{3}$ with EAcAc or DEA, dissolved in DEG or EGE were investigated using high magnetic field (11.7 T) ${ }^{27} \mathrm{Al}$ NMR spectroscopy, where the line width of peaks is sharpened. EAcAc was used as a typical $\beta$-diketone and bidentate chelating agent, and DEA as a typical alkanolamine and tridentate chelating agent. The coordination states of $\mathrm{Al}(\mathrm{O}-\mathrm{sec}-\mathrm{Bu})_{3}$ in these solvents were also examined. In addition, ${ }^{27} \mathrm{Al} \mathrm{NMR}$ spectra of $\mathrm{Al}(\mathrm{O}-\mathrm{sec}-\mathrm{Bu})_{3}$ itself and modified one dissolved in sec-butyl alcohol ( $\mathrm{sec}$ $\mathrm{BuOH}$ ) was measured ${ }^{12), 13)}$ to clarify the effect of DEG and EGE on the coordination states. From these spectra, the structure of the Al-alkoxide in DEG and EGE, and the contribution of these solvents to the chemical modification are discussed.

\section{Experimental}

${ }^{27} \mathrm{Al}$ NMR spectra were measured at $130.3 \mathrm{MHz}$ (11.7 T) using a JEOL JNM-GX500 spectrometer with pulse width of $14 \mu \mathrm{s}$ and delay time of $1 \mathrm{~s}$ between pulses, at room temperature (around $25^{\circ} \mathrm{C}$ ). Deuterated chloroform, $\mathrm{CDCl}_{3}$, was used as a solvent for the measurement and the concentration of samples was about 5-10 mass $\%$. The solution of $0.2 \mathrm{~mol} \cdot \mathrm{dm}^{-3} \mathrm{AlCl}_{3}$ in $\mathrm{D}_{2} \mathrm{O}$ was used as an external standard.

\section{Results}

Figure 1 shows the ${ }^{27} \mathrm{Al} \mathrm{NMR}$ spectra of (a) $\mathrm{Al}(\mathrm{O}-\mathrm{sec}$ $\mathrm{Bu})_{3}$ itself, and $\mathrm{Al}(\mathrm{O}-\mathrm{sec}-\mathrm{Bu})_{3}$ dissolved (b) in $\mathrm{sec}-\mathrm{BuOH}$, (c) in DEG and (d) in EGE. In the ${ }^{27} \mathrm{Al}$ NMR spectra, the peaks at $0-10,30-40,60-70 \mathrm{ppm}$ are assigned to the six-, five- and four-coordinated $\mathrm{Al}$ atoms, respectively. ${ }^{11)}$ In the ${ }^{27} \mathrm{Al}$ spectrum of $\mathrm{Al}(\mathrm{O}-\mathrm{sec}-\mathrm{Bu})_{3}$ and $\mathrm{Al}(\mathrm{O}-\mathrm{sec}-\mathrm{Bu})_{3}$ dissolved in $\sec -\mathrm{BuOH}$, Figs. 1(a) and (b), the peaks due to four-, five- and six-coordinated structural units are observed as reported in our previous paper. ${ }^{12)}$ In Fig. 1 (c) in DEG, a strong peak at $5 \mathrm{ppm}$, which is assigned to the six-coordi- 


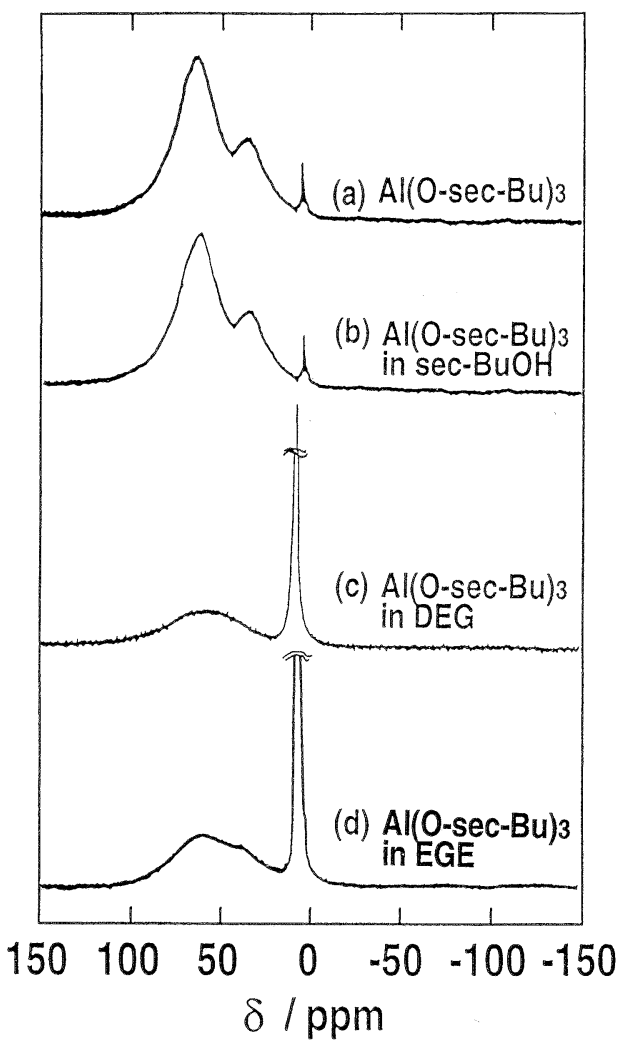

Fig. 1. ${ }^{27} \mathrm{Al} \mathrm{NMR}$ spectra of (a) $\mathrm{Al}(\mathrm{O}-\mathrm{sec}-\mathrm{Bu})_{3}$ itself, and $\mathrm{Al}(\mathrm{O}-$ $s e c-\mathrm{Bu})_{3}$ dissolved (b) in sec-BuOH, (c) in DEG and (d) in EGE.

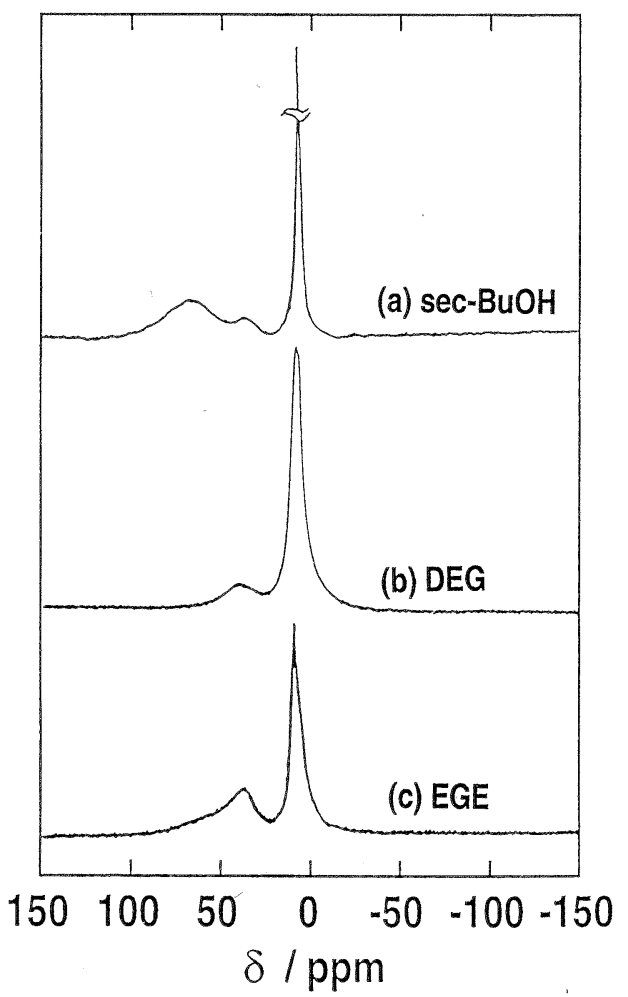

Fig. 2. ${ }^{27} \mathrm{Al} \mathrm{NMR}$ spectra of $\mathrm{Al}(\mathrm{O}-\mathrm{sec}-\mathrm{Bu})_{3}$ modified with EAcAc $\left(\mathrm{EAcAc} / \mathrm{Al}(\mathrm{O}-\mathrm{sec}-\mathrm{Bu})_{3}=1\right.$ ) dissolved in (a) sec-BuOH, (b) DEG and (c) EGE.

nated $\mathrm{Al}$ atoms, appears and a broad peak at around $65 \mathrm{ppm}$ is also observed. The spectrum in EGE shows almost the

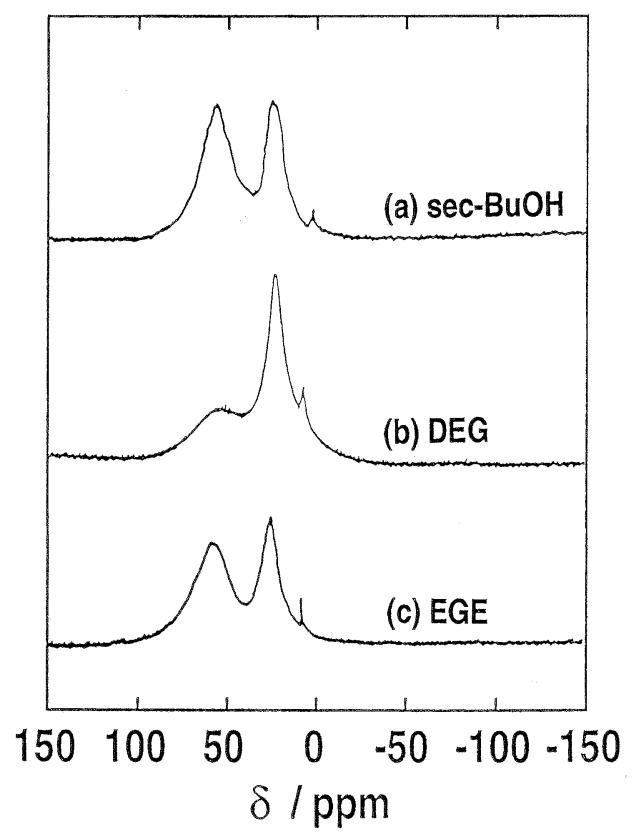

Fig. 3. ${ }^{27} \mathrm{Al} \mathrm{NMR}$ spectra of $\mathrm{Al}(\mathrm{O}-\mathrm{sec}-\mathrm{Bu})_{3}$ modified with DEA $\left(\mathrm{DEA} / \mathrm{Al}(\mathrm{O}-\mathrm{sec}-\mathrm{Bu})_{3}=1\right.$ ) dissolved in (a) $\sec -\mathrm{BuOH}$, (b) DEG and (c) EGE.

same spectrum as in DEG, but a peak at around $35 \mathrm{ppm}$, which is due to five-coordinated structural units, is observed only as a shoulder.

Figure 2 shows the ${ }^{27} \mathrm{Al} \mathrm{NMR}$ spectra of $\mathrm{Al}(\mathrm{O} \text {-sec- } \mathrm{Bu})_{3}$ modified with EAcAc (EAcAc/Al $\left.(\mathrm{O}-\mathrm{sec}-\mathrm{Bu})_{3}=1\right)$ dissolved in (a) sec-BuOH, (b) DEG and (c) EGE. As reported previously, ${ }^{12)}$ in the spectrum of $\mathrm{Al}(\mathrm{O}-\mathrm{sec}-\mathrm{Bu})_{3}$ modified with EAcAc in $s e c-\mathrm{BuOH}$, peaks due to the four", five- and six-coordinated structural units are observed. The spectra in DEG and EGE show the sharp peak due to sixcoordinated structural units and a broad peak due to fivecoordinated structural units at around $35 \mathrm{ppm}$, and a peak due to four-coordinated structural units is observed only as a shoulder.

Figure 3 shows the ${ }^{27} \mathrm{Al} \mathrm{NMR}$ spectra of $\mathrm{Al}(\mathrm{O}-\mathrm{sec}-\mathrm{Bu})_{3}$ modified with DEA $\left(\mathrm{DEA} / \mathrm{Al}(\mathrm{O}-\mathrm{sec}-\mathrm{Bu})_{3}=1\right)$ dissolved in (a) sec-BuOH, (b) DEG, and (c) EGE. In the spectrum (a), two broad peaks at around 56 and $26 \mathrm{ppm}$ are observed, as reported previously. ${ }^{13)}$ In the spectrum (b) for DEG, a strong peak at $25 \mathrm{ppm}$ and a broad and weak peak at around $55 \mathrm{ppm}$ are observed. The spectrum (c) for EGE is very similar to that for sec-BuOH, Fig. 3(a).

\section{Discussion}

It is known that the Al-alkoxides are present in a solution as oligomeric species and the structure of the species depends on the size of alkoxy groups and the concentration of the alkoxide. ${ }^{15)}$ As already reported, ${ }^{12)}$ the linear trimer composed of five-coordinated $\mathrm{Al}$ atoms between two fourcoordinated $\mathrm{Al}$ atoms (Fig. 4(a)) is assumed to be present as a major species in the solution of Figs. 1(a) and (b).

As shown in Fig. 1(c) for the spectrum of $\mathrm{Al}(\mathrm{O}-\mathrm{sec}$ $\mathrm{Bu})_{3}$ dissolved in DEG, a peak with strong intensity at around $5 \mathrm{ppm}$ was observed. This means that the substitution for $\mathrm{DEG}$ with sec-butoxy groups in $\mathrm{Al}(\mathrm{O} \text {-sec-Bu})_{3}$ leads to the formation of six-coordinated structural units. In the spectrum Fig. 1(d) for EGE, the intensity of the peak at around $5 \mathrm{ppm}$ was also increased, indicating that the reaction of $\mathrm{EGE}$ with $\mathrm{Al}(\mathrm{O}-\mathrm{sec}-\mathrm{Bu})_{3}$ leads to the formation of six-coordinated structural units. Since EGE has only one 


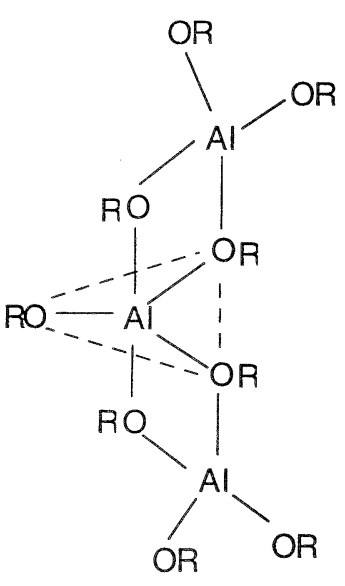

(a) $\mathrm{Al}(\mathrm{O}-\mathrm{sec}-\mathrm{Bu})_{3}$

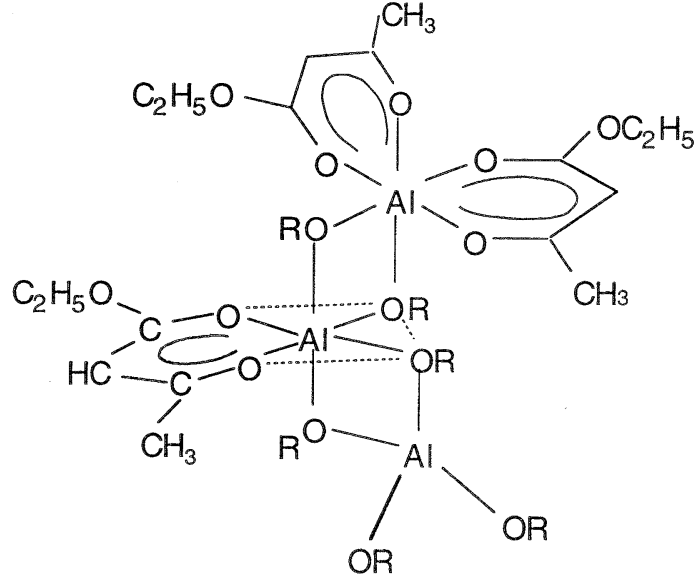

(b) EAcAc / Al(O-sec-Bu $)_{3}$

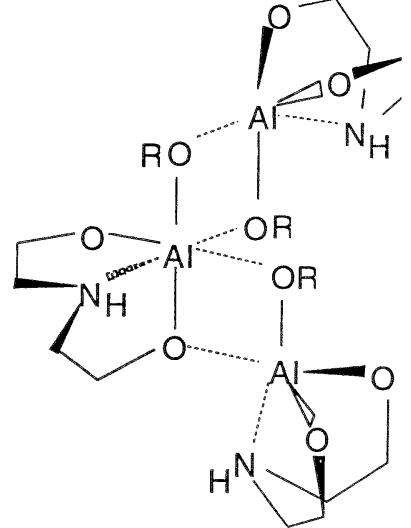

(c) DEA / Al(O-sec-Bu $)_{3}$

Fig. 4. Structural model of (a) $\mathrm{Al}(\mathrm{O}-\mathrm{sec}-\mathrm{Bu})_{3}$ itself and $\mathrm{Al}(\mathrm{O}-\mathrm{sec}-\mathrm{Bu})_{3}$ chemically modified with (b) EAcAc and (c) DEA.

-OH group in the molecule, the formation of the six-coordinated structural units is due to coordination of oxygen atom in the ether group. From the similarity of the molecular structure between DEG and EGE, Al atoms are also supposed to be coordinated by the oxygen atom in the ether group in DEG.

It is reported that $\mathrm{Al}(\mathrm{O}-\mathrm{sec}-\mathrm{Bu})_{3}$ modified with EAcAc in sec $-\mathrm{BuOH}\left(\mathrm{EAcAc} / \mathrm{Al}(\mathrm{O}-\mathrm{sec}-\mathrm{Bu})_{3}=1\right)$ is mainly present as a linear trimer, which contains two six-coordinated $\mathrm{Al}$ atoms, one being coordinated by two EAcAc and the other being coordinated by one EAcAc, and one four-coordinated $\mathrm{Al}$ atom which is not coordinated by EAcAc, ${ }^{12)}$ as shown in Fig. 4(b). In this precursor, the coordination state of the structural unit without EAcAc is assumed to be strongly affected by solvents. In the case of $s e c-\mathrm{BuOH}$ (Fig. 2(a)), the four-coordinated $\mathrm{Al}$ atoms are surrounded by sec-butoxy groups. In the spectrum Fig. 2(b) in DEG and (c) in EGE, the peak due to four-coordinated structural units was not observed, because the substitution of butoxy groups with DEG or EGE leads to the formation of six-coordinated structural units, as shown in Fig. 1. Thus, six-coordinated structural units, observed in Figs. 2(b) and (c), consist of two types of structural units, one being coordinated by EAcAc and the other one not being coordinated by EAcAc but by DEG or EGE. It should be noted that five-coordinated structural units were clearly observed in the spectrum Figs. 2(b) in DEG and (c) in EGE. These five-coordinated structural units are assumed to be formed by the substitution of one alkoxy group of four-coordinated structural units in $\mathrm{Al}(\mathrm{O}-\mathrm{sec}-\mathrm{Bu})_{3}$ modified with $\left.\mathrm{EAcAc}{ }^{12}\right)$ or in $\mathrm{Al}(\mathrm{O}-\mathrm{sec}-\mathrm{Bu})_{3}$ itself. The appearance of five-coordinated structural units indicates that four-coordinated structural units are more sensitive to structural changes due to solvents and to the reaction with EAcAc than the five-coordinated ones.

As previously reported, the peaks at 56 and $25 \mathrm{ppm}$ in Fig. 3 are assigned to the five- and six-coordinated structural units, in which $\mathrm{Al}$ atoms are coordinated by four or five oxygen atoms and one nitrogen atom;13) the coordination of one nitrogen atom instead of oxygen atom causes the peak shift of about $20 \mathrm{ppm}$ towards lower magnetic field. In the case of $\mathrm{DEA} / \mathrm{Al}(\mathrm{O}-\mathrm{sec}-\mathrm{Bu})_{3}=1$, each $\mathrm{Al}$ atom in the precursors is assumed to be coordinated by one DEA molecule, ${ }^{13)}$ as shown in Fig. 4(c). From this structural model, the effect of solvents on the coordination state of structural units is assumed to be very small. The result that the spectrum for EGE (Fig. 3(c)) was very similar to that in sec-BuOH (Fig. 3(a)) is consistent with this assumption. However, in Fig. 3 (b) in DEG, the relative intensity of the peak at around 56 ppm was weaker than that of Fig. 3 (a) in sec- $\mathrm{BuOH}$ and (c) in EGE, due to the broadening of this peak. This shows that the complexing ability of DEG is stronger than that of EGE, and DEG substitutes the secbutoxy group in $\mathrm{Al}(\mathrm{O}-\mathrm{sec}-\mathrm{Bu})_{3}$. Substitution of sec-butoxy group in $\mathrm{Al}(\mathrm{O}-\mathrm{sec}-\mathrm{Bu})_{3}$ with $\mathrm{DEG}$, which has two or three coordination sites, must result in decreasing the symmetry of the structural units, and the peak becomes very broad.

\section{Conclusion}

${ }^{27} \mathrm{Al}$ NMR spectra revealed that the reaction of $\mathrm{DEG}$ or $\mathrm{EGE}$ with $\mathrm{Al}(\mathrm{O}-\mathrm{sec}-\mathrm{Bu})_{3}$ led to the formation of six-coordinated structural units. It was indicated that the formation of the six-coordinated structural units was due to the coordination of oxygen atom in the ether group in DEG or EGE. Four-coordinated structural units were not observed in $\mathrm{Al}(\mathrm{O}-\mathrm{sec}-\mathrm{Bu})_{3}$ modified with EAcAc in EGE or DEG, and two types of six-coordinated structural units, one being coordinated by EAcAc and the other one being not coordinated by EAcAc but by DEG or EGE, were observed. The effect of solvent on the coordination state of structural units modified with DEA was very small. Substitution of secbutoxy group in $\mathrm{Al}(\mathrm{O}-\mathrm{sec} \text { - } \mathrm{Bu})_{3}$ modified with $\mathrm{DEA}$ for $\mathrm{DEG}$ resulted in decreasing the symmetry of the structural units, in which $\mathrm{Al}$ atoms were coordinated by four or five oxygen atoms and one nitrogen atom, and the peak due to the structural units became very broad.

Acknowledgment The present study was supported by a Grant-in-Aid from the Ministry of Education, Science, Sports and Culture of Japan.

\section{References}

1) R. C. Mehrotra and A. K. Rai, Polyhedron, 10, 1967-94 (1991).

2) C. Sanchez and F. Ribot, New J. Chem., 18, 1007-47 (1994).

3) H. Uchihashi, N. Tohge and T. Minami, J. Ceram. Soc. Japan (Seramikkusu Ronbunshi), 97, 389-99 (1989).

4) K. Shinmou, N. Tohge and T. Minami, Jpn. J. Appl. Phys., 33, L1181-84 (1994). 
5) N. Tohge, K. Shinmou and T. Minami, J. Sol-Gel Sci. Technol., 2, 581-85 (1994).

6) H. Tanaka, K. Tadanaga, N. Tohge and T. Minami, Jpn. J. Appl. Phys., 34, L1155-57 (1995).

7) R. Nass and H. Schmidt, J. Non-Cryst. Solids, 121, 329-33 (1990).

8) T. Heinrich, F. Raether, W. Tappert and J. Fricke, J. NonCryst. Solids, 145, 55-59 (1992).

9) T. Heinrich, F. Raether, O. Sparmann and J. Fricke, J. Appl. Cryst., 24, 788-93 (1991).

10) L. Bonhomme-Coury, F. Babonneau and J. Livage, J. Sol-Gel Sci. Tech., 3, 157-68 (1994).
11) K. Tadanaga, T. Minami and N. Tohge, Chem. Lett., 150710 (1994).

12) K. Tadanaga, T. Iwami, N. Tohge and T. Minami, J. Sol-Gel Sci. Tech., 3, 5-10 (1994).

13) K. Tadanaga, S. Ito, T. Minami and N. Tohge, J. Non-Cryst. Solids, 201, 231-36 (1996).

14) K. Maeda, F. Mizukami, S. Niwa, M. Toba, M. Watanabe and K. Masuda, J. Chem. Soc. Faraday Trans., 88, 97-104 (1992).

15) O. Kriz, B. Casensky, A. Lycha, J. Fusek and S. Hermanek, J. Mag. Reson., 60, 375-81 (1984). 